\section{Lord Bledisloe and the Promotion of Science}

Lond Buediseos, the Governor-General of New Zealand, has consistently encouraged scientific workers in the Dominion, and has promoted endeavours in all branches of science. As evidence of his keen scientific interest, during the visit of the Byrd Expedition II to Wellington on December 9, Lord Bledisloe promoted a happy scientific colloquium at Government House, when the visiting explorers were entertained along with the permanent scientific workers of the Dominion. It is more than twenty years since so large a number of men belonging to different nationalities, whose researches are outstanding in different branches of science, have been gathered around one table in New Zealand. The function allowed group discussions of all branches of the scientific work of the Expedition, which is probably provided with a larger scientific staff, and has a more extended scientific programme, than any expedition which has so far visited the antarctic. Of outstanding interest is the work projected in cosmic ray determinations, and it is understood that the results on the trip from the United States have verified A. H. Compton's results in the variation with latitude of cosmic ray intensity. The results of observations in the neighbourhood of the magnetic pole and on the polar plateau will be awaited with interest.

\section{The Byrd Antarctic Expedition}

Among the interesting items in the programme of work of the Byrd Antarctic Expedition are the use of seismic reflection methods for the determinations of ice thickness and depth. For this work, the expedition is well equipped with the latest types of apparatus. Close attention will be devoted to upper air observations as forming a very considerable part of the extensive meteorological research programme which has been outlined. The expedition is also proposing to take the fullest advantage of the opportunities afforded in this region for studying polar aurora. The biological and geological problems associated with Antarctica will also receive close study, and the scientific world should be considerably richer as the result of the labours of the staff of the Byrd Expedition II in the south polar regions.

We regret that news of the Expedition up to the end of January was not of a wholly reassuring nature. According to the Times, the larger of the two vessels of the expedition, Jacob Ruppert, was caught in the pack-ice and drifting in the Ross Sea. Apparently the ship had met with much difficulty on account of ice but had reached the proximity of the Ross Barrier by January 27; it began to discharge cargo on to the ice whence it was to be sledged by dogs and tractor to the base at Little America on the Bay of Whales. The following day, however, rifts appeared in the ice and several drums of petrol were saved with difficulty. The ship had to cast off, leaving a large party of men on the ice. The time now available for landing supplies is short since the ice is likely to freeze together at any time now, thus endangering the safety of the ship or at least its chance of getting away before the winter sets in.

\section{Research and the Electrical Industry}

THE thirteenth annual report of the British Electrical and Allied Industries Research Association for the year ended September 1933 gives an interesting résumé of the many problems on which it is engaged. In a foreword, Mr. C. C. Paterson, the chairman of the Council, says that the electrical industry has been built up by research, and by research only can it continue to prosper. This research must be made on a scale commensurate with its growth. Some of the researches described have a longer outlook than others, but none of the researches can be abandoned or even delayed without definite loss to the industry as a whole. Much of the work done is in co-operation with other organisations. It is a pity that a number of large authorised electrical undertakings have not yet seen their way to become full subscribing members. The subscription assess. ment agreed to, at a recent conference, was $£ 10$ per $\mathfrak{£ 2 5 , 0 0 0}$ of revenue. It is certainly not onerous. Research has often the effect of appreciably, and sometimes largely, reducing capital and working costs and hence non-subscribers are benefiting from work, the cost of which has been borne by others. The High Commissioners in London for the Dominions and Colonies have shown an active interest in the work of the Association, particularly the Indian Government. Applications for membership have been received from several local State Governments and Public Works Departments. We are glad to hear that the Association is taking an active part in locating the causes of radio interference. The solution of these urgent problems has involved sacrifices by the staff. They have been able to mobilise a squadron for field work and a mobile laboratory at short notice and are obtaining useful information.

\section{Industrial Health in Japan}

IN Japan the pressure of a growing population has focused attention on the further development of industry, since in the next decade Japan has to find food and employment for nearly ten million more people than she does to-day. That the problem of industrial efficiency is being seriously tackled is evidenced in the annual report of the Director of the Japanese Institute of the Science of Labour at Kurasiki. This Institute was founded some years ago to undertake research into the physiological, psychological and environmental conditions affecting workers and their output. Research committees have recently been organised to investigate problems such as the rationalisation of labour, industrial fatigue, factory conditions and the appropriate qualifications to be desired of workers in every branch of Japanese industrial life. This latter investigation has already led to the establishment of standard norms for the mental and physical development of young Japanese workers aged 12-20 years. Occupational diseases

(Continued on p. 253.) 